\title{
Growth of Containerized Eastern Redcedar Amended with Dolomitic Limestone and Micronutrients
}

\author{
Robert D. Wright \\ Department of Horticulture, Virginia Polytechnic Institute and State \\ University, Blacksburg, VA 24061-0327
}

\section{Eric Hinesley \\ Department of Horticultural Science, North Carolina State University, Raleigh, NC 27695-7609}

Additional index words. Juniperus virginiana, $\mathrm{pH}$, nursery crops, nutrition

\begin{abstract}
Eastern redcedar (Juniperus virginiana L.) seedlings were grown in 1986 through 1988 in pine bark container media with various levels of dolomitic limestone and micronutrients. Supplemental micronutrients reduced shoot growth, especially in the absence of limestone, and root growth was greatest when neither limestone nor micronutrients were added. Including at least $3.0 \mathrm{~kg}$ limestone $/ \mathrm{m}^{3}$ in the medium was beneficial, not only as a source of nutrients, but also as a buffer against potentially toxic effects of excess micronutrients.
\end{abstract}

Adding limestone and micronutrients as amendments to nursery container media is a common practice. Occasionally, however, adding limestone to media, such as pine bark, can inhibit the growth of some woody species, e.g., holly, azalea (Chrustic and Wright, 1983), and Fraser fir (Bryan et al., 1989), whereas species such as juniper show improved growth (Chrustic and Wright, 1983). Other work has shown that adding micronutrients to pine bark media is questionable in terms of improving growth (Leda, 1986).

Solubility of most micronutrients in mineral soils increases at lower $\mathrm{pH}$ (Tisdale et al.; 1985). Thus, the micronutrient content of container media, such as composted pine bark, might be sufficient to meet plant needs if the $\mathrm{pH}$ of the medium is relatively low. However, if high levels of micronutrients are added to the medium, adjusting the $\mathrm{pH}$ might be necessary to prevent micronutrient toxicity.

Eastern redcedar is widely distributed in the eastern United States and is used for a variety of purposes, including posts, windbreaks, furniture, Christmas trees, and landscaping. It is grown on a wide variety of soils, but develops best on well-drained soils high in exchangeable $\mathrm{Ca}, \mathrm{K}$, and $\mathrm{Mg}$, with a pH near neutral (Fletcher and Ochrymowych, 1955). Redcedar litter has a high $\mathrm{Ca}$ concentration and, consequently, tends to increase $\mathrm{Ca}$ levels and $\mathrm{pH}$ in the surface soil beneath the crown (Broadfoot, 1951; Coile, 1933; Read and Walker, 1950). Little is known about the nutrition of eastern redcedar in soilless mixes. We investigated the influence of micronutrient and limestone additions on the growth of Juniperus vir-

Received for publication 13 Mar. 1990. The cost of publishing this paper was defrayed in part by the payment of page charges. Under postal regulations, this paper therefore must be hereby marked advertisement solely to indicate this fact. giniana in composted pine bark media.

A series of experiments was conducted during 1986 through 1988. Procedures and plant material were similar in all experiments. Because the last experiment in 1988 'was conducted in greatest detail, only procedures for that experiment are described.

One-year-old eastern redcedar seedlings were- lifted (15 Mar. 1988) from a seedbed in the North Carolina Forest Service Nursery, Goldsboro. Plants were selected to be vigorous and uniform with a height of 25 to $30 \mathrm{~cm}$. Plants were heeled into boxes containing nursery soil and transported to Raleigh, N. C., where they were stored at 4C and received a 6-h daily photoperiod from cool-white fluorescent light (photosynthetic photon flux $=27$ to $38 \mu \mathrm{mol} \cdot \mathrm{s}^{-1} \cdot \mathrm{m}^{-2}$ at plant level). On 29 Mar. 1988, plants were transplanted into 20-liter pots containing a 5 aged pine bark : 1 sand (v/v) mix. The medium initially contained $3 \mathrm{~kg}$ of triple superphosphate $/ \mathrm{m}^{3}(0.0 \mathrm{~N}-20.0 \mathrm{P}-0.0 \mathrm{~K})$, gypsum $\left(1.5 \mathrm{~kg} \cdot \mathrm{m}^{3}\right)$, plus factorial combinations of finely ground dolomitic limestone $\left(0\right.$ and $\left.3 \mathrm{~kg} \cdot \mathrm{m}^{3}\right)$ and micronutrients $(0,0.5$, 1.0 , and $1.5 \mathrm{~kg} \cdot \mathrm{m}^{3}$ ) (Micromax; Sierra Chemical Co., Milpitas, Calif.).

Pots were arranged in a randomized complete-block design on outdoor gravel beds with overhead irrigation. There were 18 single-plant replications, with eight pots per block.

Plants were subsequently topdressed with 30 g Osmocote/pot $(18 \mathrm{~N}-2.8 \mathrm{P}-10 \mathrm{~K}$, Sierra Chemical) on 4 Apr. and 20 May 1988. Pots received overhead irrigation for 30 to $60 \mathrm{~min}$ daily throughout the growing season.

Foliage sampling and analysis. Foliage samples were collected on 16 May, 25 July, and 3 Oct. 1988. One small branch tip from the upper half of the crown was taken from each plant on each sampling date. Tissue was composite from replications 1-4, 5-9, 1013 , and $14-18$ to provide four replications for laboratory analysis. Samples were stored at $-3 \mathrm{C}$, later dried to constant weight at $65 \mathrm{C}$, ground in a Wiley mill to pass a 20 mesh sieve, and redried before chemical analyses. Plant $\mathrm{N}$ was analyzed via microKjeldahl (Peterson and Chesters, 1964), P colormetrically (Watanabe and Olsen, 1965), and other nutrients by atomic absorption spectroscopy.

Nutrient status of medium. The pourthrough (PT) method (Yeager et al., 1983) of nutrient extraction was used to evaluate nutrient status of the growing medium on the same dates that foliage samples were collected. Four of the 18 replications were selected and used throughout the experiment for PT sampling. On each occasion, pots were watered and allowed to drain. After adding $350 \mathrm{ml}$ of distilled water to the surface of each pot, a 100- to 150-ml aliquot of leachate was collected and frozen for subsequent analysis. Nitrate- $\mathrm{N}$ and $\mathrm{NH}_{4}-\mathrm{N}$ were analyzed via ion-selective electrodes and other nutrients via a Jarrell-Ash ICAP 9000 spectrophotometer (Jarrell-Ash, Franklin, Mass.).

The experiment was terminated in early Nov. 1988. Roots were placed on screens and washed with a high-pressure water stream to remove all medium. A small portion of roots $(<2 \mathrm{~mm}$ in diameter) from each plant was composite for chemical analysis according to the same procedure used for foliage analysis. Height of each plant was measured, and dry weights of shoots and roots were determined.

Data analysis. The data for various growth characteristics and tissue analysis and PT values were evaluated with analysis of variance and regression analysis, using SAS (SAS Institute, 1985). Linear, quadratic, and cubic effects for limestone and micronutrients were tested for significance, where appropriate.

Adding micronutrients to the container medium without limestone reduced shoot growth (Table 1). In 1988, this occurred whether limestone was present in the medium or not. In cases where micronutrients clearly affected growth, the relationship was linear with a negative slope. In every experiment, there was at least one significant limestone $\times$ micronutrient interaction, but interactions did not occur consistently across all three experiments for any of the growth indices. In 1986 and 1987, micronutrient additions in conjunction with limestone either resulted in no effect on shoot growth (1986) or tended to increase shoot weight, especially at the $1.5 \mathrm{~kg} \cdot \mathrm{m}^{-3}$ rate (1987). In two of the three experiments, root growth was significantly reduced in the presence of supplemental micronutrients, especially in the absence of limestone.

Medium solution $\mathrm{pH}$ was increased by about two $\mathrm{pH}$ units with the addition of limestone (Table 2). With limestone addition, $\mathrm{NH}_{4}^{+}-\mathrm{N}$ levels were relatively low, whereas $\mathrm{NO}_{3}^{-}-\mathrm{N}$ levels were similar with and without limestone. Calcium, $\mathrm{Mg}$, and $\mathrm{Mn}$ levels were higher and Fe levels lower in the presence of limestone. Adding micronutrients did not influence Fe levels in the medium solution, but Mn levels were increased. 
Table 1. Influence of limestone and micronutrient additions to pine bark on growth and dry weight accumulation of Juniperus virginiana.

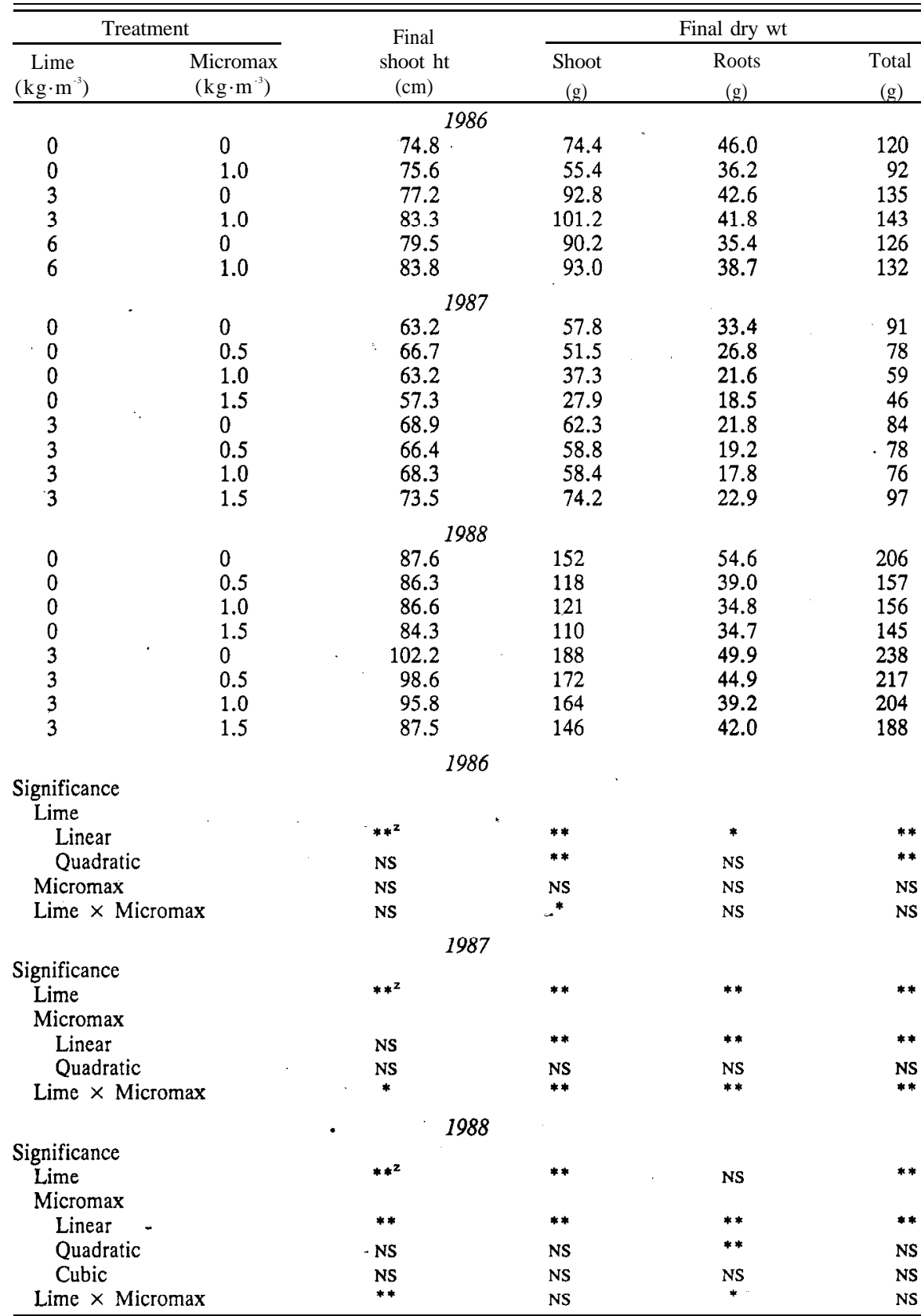

${ }^{2}$ Replications $=12$ in 1986,10 in 1987,18 in 1988. Significance tests based on type I SS; $* *$ s 0.01 , $* \leq 0.05$, NS $>0.05$.
Foliar tissue $\mathrm{Ca}$ was not increased by limestone additions (Table 3). Magnesium, $\mathrm{Mn}, \mathrm{Al}$, and B tissue levels for limestone treatments were higher than controls, whereas tissue levels of other nutrients were not affected. Zinc was not detectable. The only nutrient that increased in the medium solution in response to micronutrient additions was Mn.

Root $\mathrm{Mg}, \mathrm{Mn}, \mathrm{Zn}$, and $\mathrm{S}$ tissue levels were higher with limestone additions, whereas other nutrients were not affected. Iron, $\mathrm{Zn}$, and $\mathrm{Cu}$ increased in roots with increasing micronutrient additions. The increase in $\mathrm{Zn}$ associated with addition of micronutrients occurred in the presence of limestone.

Adding micronutrients to pine bark medium in the absence of limestone reduced plant growth in all three years. Increased micronutrient volubility and toxicity at low $\mathrm{pH}$ can occur in mineral soils and might explain this result (Tisdale et al., 1985). However, micronutrient toxicity was not confirmed by higher levels of these metals in the medium solution and plant foliage (Tables 2 and 3). We also cannot explain why Mn was higher with than without limestone.

Micronutrient interactions in organic soils/ media are complex and not well understood (Stevenson and Ardakani, 1972). Micromax contains $12 \% \mathrm{Fe}$ and only $2.5 \% \mathrm{Mn}$, yet a greater concentration of Mn than Fe was found * - in the medium solution.. Organic soil frac* tions tend to adsorb Fe more readily than Mn ss (Stevenson and Ardakani, 1972), which could account for less $\mathrm{Fe}$ than $\mathrm{Mn}$ in the medium solution.

Nonlimed plants in 1988 that received higher levels of micronutrients exhibited less vigor and growth and more foliar injury early in the growing season than limed plants. Several plants developed weak leaders that would not remain upright. As the season progressed, visual differences were less apparent. Observations of roots at the conclusion of the study suggested that they were injured early in the season, followed by partial recovery. These symptoms were minimal in limed plants. Plants that received no limestone or micronutrients were healthy and had maximum root growth. The added $\mathrm{Ca}$ from limestone might have provided protection

Table 2. Influence of limestone and micronutrient addition on leachate $\mathrm{pH}$ and nutrient content of a pine bark medium (measured in May and Oct. 1988). ${ }^{2}$

\begin{tabular}{|c|c|c|c|c|c|c|c|c|c|c|c|c|c|c|c|}
\hline \multirow{3}{*}{$\begin{array}{c}\text { Lime } \\
\left(\mathrm{kg} \cdot \mathrm{m}^{-3}\right)\end{array}$} & \multirow{3}{*}{$\begin{array}{c}\operatorname{Micromax} \\
\left(\mathrm{kg} \cdot \mathrm{m}^{-3}\right)\end{array}$} & \multirow{2}{*}{\multicolumn{2}{|c|}{$\begin{array}{c}\text { Leachate } \\
\text { pH }\end{array}$}} & \multicolumn{12}{|c|}{ Concn $(\mathrm{ppm})$ in leachate } \\
\hline & & & & \multicolumn{2}{|c|}{$\mathrm{N} \mathrm{H}_{4}^{+}-\mathrm{N}$} & \multicolumn{2}{|c|}{$\mathrm{NO}_{3}^{-}-\mathrm{N}$} & \multicolumn{2}{|c|}{$\mathrm{Ca}$} & \multicolumn{2}{|c|}{$\mathrm{Mg}$} & \multicolumn{2}{|c|}{$\mathrm{Fe}$} & \multicolumn{2}{|c|}{$\mathrm{Mn}$} \\
\hline & & May & Oct. & May & Oct. & May & Oct. & May & Oct. & May & Oct. & May & Oct. & May & Oct. \\
\hline 0 & 0 & 4.0 & 3.7 & 12 & 1.0 & 2.5 & 4.2 & 68 & 22 & 3 & 2 & 0.38 & 0.13 & 0.22 & 0.02 \\
\hline 0 & 1.0 & 3.9 & 4.0 & 4.5 & 2.0 & 4.2 & 6.0 & 62 & 28 & 3 & 3 & 0.29 & 0.22 & 0.70 & 0.10 \\
\hline 0 & 1.5 & 3.9 & 3.8 & 5.0 & 3.0 & 5.5 & 5.5 & 70 & 23 & 4 & 3 & 0.32 & 0.25 & 0.68 & 0.08 \\
\hline 3 & 0 & 5.5 & 6.1 & 0.5 & 1.0 & 1.8 & 5.2 & 83 & 30 & 22 & 11 & 0.21 & 0.08 & 0.44 & 0.01 \\
\hline 3 & 1.5 & 4.9 & 5.8 & 2.2 & 0.5 & 4.8 & 4.0 & 109 & 28 & 22 & 9 & 0.29 & 0.09 & 4.10 & 0.12 \\
\hline \multicolumn{16}{|c|}{ Significance ${ }^{y}$} \\
\hline Lime & & $* *$ & $* *$ & * & ** & NS & NS & $* *$ & NS & $* *$ & $* *$ & ** & $* *$ & $* *$ & * \\
\hline Micron & & ** & NS & NS & NS & NS & NS & NS & NS & NS & NS & NS & NS & ** & ** \\
\hline Lime $>$ & icromax & $*$ & NS & NS & NS & NS & NS & NS & NS & NS & NS & NS & NS & ** & $*$ \\
\hline
\end{tabular}

${ }^{2} 16$ May; 3 Oct.

'Four Replications; significance tests $* * \leq 0.01, * \leq 0.05$, NS $>0.05$. 


\begin{tabular}{|c|c|c|c|c|c|c|c|c|c|c|c|c|c|}
\hline \multirow{3}{*}{$\begin{array}{c}\text { Lime } \\
\left(\mathrm{kg} \cdot \mathrm{m}^{-3}\right)\end{array}$} & \multirow{3}{*}{$\begin{array}{c}\text { Micromax } \\
\left(\mathrm{kg} \cdot \mathrm{m}^{-3}\right)\end{array}$} & \multicolumn{12}{|c|}{ Elemental content or concn } \\
\hline & & $\mathrm{P}$ & $\mathrm{K}$ & $\mathrm{Ca}$ & $\mathrm{Mg}$ & $\underline{\mathrm{Mn}}$ & $\mathrm{Zn}$ & $\mathrm{Fe}$ & $\mathrm{Al}$ & $\mathrm{Cu}$ & $\mathrm{B}$ & $\mathrm{Na}$ & $\mathrm{s}$ \\
\hline & & \multicolumn{4}{|c|}{$(\%)$} & \multicolumn{8}{|c|}{$(\mathrm{ppm})$} \\
\hline \multicolumn{14}{|c|}{ Foliage } \\
\hline 0 & 0 & 0.20 & 0.87 & 0.54 & 0.09 & 40 & 0 & 33 & 37 & 9 & 13 & 326 & 542 \\
\hline 0 & 0.5 & 0.18 & 0.86 & 0.50 & 0.08 & 52 & 0 & 42 & 47 & 7 & 14 & 316 & 556 \\
\hline 0 & 1.0 & 0.21 & 0.88 & 0.62 & 0.10 & 56 & 0 & 60 & 42 & 9 & 14 & 360 & 662 \\
\hline 0 & 1.5 & 0.21 & 0.93 & 0.56 & 0.11 & 58 & 0 & 49 & 44 & 9 & 15 & 388 & 654 \\
\hline 3 & 0 & 0.19 & 0.79 & 0.52 & 0.15 & 41 & 0 & 36 & 35 & 6 & 11 & 743 & 584 \\
\hline 3 & 0.5 & 0.22 & 0.85 & 0.53 & 0.18 & 60 & 0 & 48 & 35 & 7 & 12 & 353 & 597 \\
\hline 3 & 1.0 & 0.23 & 0.93 & 0.56 & 0.19 & 68 & 0 & 46 & 39 & 9 & 12 & 398 & 688 \\
\hline 3 & 1.5 & 0.21 & 0.87 & 0.52 & 0.16 & 80 & 0 & 42 & 29 & 9 & 12 & 304 & 651 \\
\hline Significance ${ }^{z}$ & & & & & & . & & & & & & & \\
\hline Lime & & NS : & NS & NS & $* *$ & $*$ & $\ldots$ & NS & $*$ & NS & $* *$ & NS & NS \\
\hline Micromax & & NS & NS & NS & NS & ** & $\cdots$ & NS & NS & NS & NS & NS & NS \\
\hline \multicolumn{14}{|c|}{ Root } \\
\hline 0 & 0 & 0.21 & 0.92 & 0.32 & 0.07 & 9 & 0 & 100 & 188 & 8 & 7 & 746 & 1116 \\
\hline 0 & 0.5 & 0.21 & 1.03 & 0.43 & 0.07 & 12 & 0 & 123 & 184 & 13 & 9 & 799 & 1018 \\
\hline 0 & $1.0^{\circ}$ & 0.22 & 1.06 & 0.58 & 0.08 & 13 & 16 & 127 & 155 & 19 & 9 & -804 & 1130 \\
\hline 0 & 1.5 & 0.21 & 0.94 & 0.40 & 0.07 & 11 & 0 & 163 & 164 & 18 & 8 & 750 & 979 \\
\hline 3 & 0 & 0.24 & 1.00 & 0.49 & 0.15 & 17 & 9 & 109 & 190 & 8 & 8 & 985 & 1589 \\
\hline 3 & 0.5 & 0.21 & 0.92 & 0.36 & 0.11 & 20 & 18 & 84 & 138 & 18 & 7 & 738 & 1276 \\
\hline 3 & 1.0 & 0.23 & 1.04 & 0.47 & 0.13 & 29 & 52 & 226 & 174 & 19 & 9 & 764 & 1426 \\
\hline 3 & 1.5 & 0.25 & 1.12 & 0.46 & 0.15 & 26 & 91 & 205 & 224 & 31 & 9 & 790 & 1555 \\
\hline \multicolumn{14}{|l|}{ Significance ${ }^{z}$} \\
\hline Lime & & NS & NS & NS & $* *$ & $* *$ & $* *$ & NS & NS & NS & NS & NS & $*$ \\
\hline Micromax & & NS & NS & NS & NS & NS & $*$ & $*$ & NS & $* *$ & NS & NS & NS \\
\hline
\end{tabular}

${ }^{2}$ Significance tests: $* * \leq 0.01, * \leq 0.05$, NS $>0.05$.

from toxic effects of excess micronutrients (Wallace et al., 1966), especially just after p 1 a $\mathrm{n} \mathrm{t}$ i n g.

In the presence of limestone, there was little benefit to adding micronutrients. Only in 1987-and then only at the highest micronutrient rate $\left(1.5 \mathrm{~kg} \cdot \mathrm{m}^{-3}\right)$ - was there an advantage. Apparently, sufficient micronutrients for growth were supplied by the bark medium, irrigation water, or fertilizer impurities. Lack of growth response to added micronutrients with pine bark was previously demonstrated with Juniperus chinensis, Ilex crenata, Ligustrum lucidum, and Tagetes erecta (Leda, 1986).

Increased shoot growth due to limestone, when no micronutrients were added, indicated that additions of $\mathrm{Ca}$ and/or $\mathrm{Mg}$ were needed. Limestone requirements for woody plant growth can be satisfied by additions of calcium and magnesium sulfate (Fuller and Meadows, 1983). Limestone could also have produced a more favorable $\mathrm{NO}_{3}-\mathrm{N}: \mathrm{NH}_{4}-\mathrm{N}$ ratio due to increased vitrification at a higher pH (Niemiera and Wright, 1986a, 1986b). A more acceptable cation/anion balance due to increased $\mathrm{Ca}$ and $\mathrm{Mg}$ from limestone might also have increased growth with limestone additions, especially when micronutrients were added (Wallace et al., 1966).

We have demonstrated the importance of a proper balance between limestone and micronutrient additions for juniper. Incorporating at least $3.0 \mathrm{~kg} \cdot \mathrm{m}^{-3}$ of limestone is beneficial. Micronutrient additions in conjunction with limestone appear unnecessary ' and, more importantly, can be deleterious without limestone.

\section{Literature Cited}

Broadfoot, W.M. 1951. Soil rehabilitation under eastern redcedar and loblolly pine. J. For. 49:780-781

Bryan, J.A., J.R. Seiler, and R.D. Wright. 1989 Influence of growth medium $\mathrm{pH}$ on the growth of container-grown fraser seedlings. J. Env. Hort. 7:62-64.

Chrustic, G.A. and R.D. Wright. 1983. Influence of liming rate on holly, azalea and juniper growth in pine bark. J. Amer. Soc. Hort. Sci. 108:791795

Coile, T.S. 1933. Soil reaction and forest types in the Duke Forest. Ecology 14:323-333.

Fletcher, P.W. and J. Ochrymowych. 1955. Mineral nutrition and growth of eastern redcedar in Missouri. Missouri Agr. Expt. Sta. Res. Bul. 577.

Fuller, D.L. and W.A. Meadows. 1983. Effects of powdered vs. pelletized dolomite and two fertilizer regimes on $\mathrm{pH}$ of growth medium and quality of eight woody species in containers. S. Nurseryman Res. J. 9:1-7.

Leda, C.E. 1986. Iron and manganese requirements of containerized plants growing in pine bark. MS Thesis, Virginia Polytechnic Inst. and State Univ., Blacksburg.

Niemiera, A.X. and R.D. Wright. 1986a. The influence of vitrification on the medium solution and growth of holly, azalea, and juniper in a pine bark medium. J. Amer. Soc. Hort. Sci.
111:708-712.

Niemiera, A.X. and R.D. Wright. 1986b. Effect of liming rate on vitrification in a pine bark medium. J. Amer. Soc. Hort. Sci. 111:713715.

Peterson, H.C. and G. Chesters, 1964. A reliable total nitrogen determination of plant tissue accumulating nitrate nitrogen. Agron. J. 56:8990

Read, R.A. and L.C. Walker. 1950. Influence of eastern redcedar on soil in Connecticut pine plantations. J. For. 48:337-339 [537-539].

SAS Institute, Inc. 1985. SAS user's guide: Statistics, version 5 edition. SAS Inst., Inc., Cary, N.C.

Stevenson, F.J. and M.S. Ardakani. 1972. Organic matter reactions involving micronutrients in soils, p. 79-110. In: J.J. Mortdvedt, D.M. Giordano, and W.L. Lindsay (eds.). Micronutrients in agriculture. Soil Sci. Soc. Amer., Madison, Wis.

Tisdale, S.L., W.L. Nelson, and J.D. Beaten. 1985. Soil fertility and fertilizers. 4 th ed. Macmillan, New York.

Wallace, A., E. Frolich, and O.R. Lund. 1966. Calcium requirements of higher plants. Nature 209:634.

Watanabe, F.S. and S.R. Olsen. 1965. Test of an ascorbic acid method for determining phosphorus in water and $\mathrm{NaHCO}_{3}$ extracts from soil. Soil Sci. Soc. Amer. Proc. 29:677-678.

Yeager, T.H., R.D. Wright, and S.J. Donohue. 1983. Comparison of pour-through and saturated pine bark extract $\mathrm{N}, \mathrm{P}, \mathrm{K}$, and $\mathrm{pH}$ levels. J. Amer. Soc. Hort. Sci. 108:112-114. 